Ramineli, S.M.; Godoy, E.; Cratinguy, M.A.; Ribeiro, T. Projeto Leme Consciente: ordenamento do turismo náutico em Paraty (RJ). Anais do VIII Congresso Nacional de Ecoturismo e do IV Encontro Interdisciplinar de Ecoturismo em Unidades de Conservação. Revista Brasileira de Ecoturismo, São Paulo, v.4, n.4, 2011, p. 572.

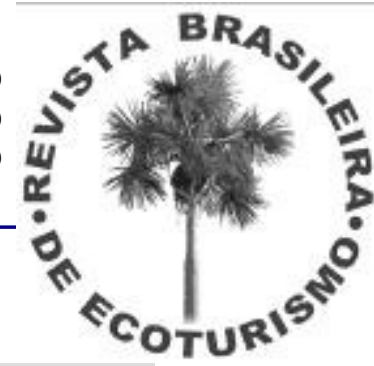

\title{
PROJETO LEME CONSCIENTE: ORDENAMENTO DO TURISMO NÁUTICO EM PARATY (RJ)
}

\author{
Suzana Muniz Ramineli*, Eduardo Godoy ${ }^{* *}$, Marco Antônio Cratinguy ${ }^{\star * *}$, Tatiana Ribeiro** \\ *Projeto Hippocampus/Naturaulas Cursos Ambientais/Universidade Federal Fluminense (PGCA), \\ ${ }^{* *}$ ICM Bio / APA Cairuçu, ${ }^{* * *}$ Kyrie Dive
}

E-mails: suzanaramineli@gmail.com, easgodoy@gmail.com, kyrie@kyriedive.com.br,

Fundado em 1667, tombado pelo Patrimônio Histórico Nacional e tendo 80\% do território protegidos por unidades de conservação (UCs), Paraty, RJ desperta interesse por aspectos naturais, culturais e históricos. A maior parte de seu mar está na Baía da llha Grande, e o município conta com 63 ilhas e 43 praias, tendo no turismo e na pesca suas principais atividades econômicas. A maioria dos roteiros turísticos marítimos também está nas UCs: APA Cairuçu, ESEC Tamoios (Federais), RESEC Juatinga (Estadual) e APA da Baía de Paraty (Municipal). A apenas uma (ESEC Tamoios) é restritiva ao turismo. As demais poderiam até potencializar o turismo náutico, desde que sustentavelmente, já que essa atividade depende de qualidade ambiental e dos recursos naturais conservados. Entretanto, embora Paraty tenha grande vocação para o ecoturismo, ainda há muitas práticas insustentáveis, como o lançamento de lixo, esgoto e óleo no mar. O objetivo geral do Projeto Leme Consciente é sensibilizar o público-alvo (mestres e marinheiros) para a importância da preservação do ambiente marinho. Os objetivos específicos são: fomentar o senso de pertencimento dos participantes pela cidade e seu mar; ouvir as impressões sobre o turismo náutico local; oferecer ferramentas sustentáveis à atividade; abrir espaço de diálogo entre setor, UCs e projetos ambientais em Paraty; conservar os ecossistemas da Baía da Ilha Grande; incentivar o "briefing" ambiental para saídas turísticas. O público-alvo foi convidado em seu local de trabalho, o cais de turismo de Paraty. O início do Projeto Leme Consciente se deu com oficina realizada de 15 a 18/08/11, das $18 \mathrm{~h}$ às $22 \mathrm{~h}$, dividida nos seguintes temas diários: "Descobrindo a realidade náutica de Paraty"; "Breve história paratiense e a segurança no mar"; "Ambiente marinho: belezas, conservação, ameaças e alertas"; "Retrospectiva e planos para um futuro próximo". Foi significativo o espaço para que os participantes expusessem suas considerações sobre o turismo náutico, tirassem dúvidas sobre os conteúdos abordados na oficina e trocassem experiências. Percebeu-se uma rivalidade forte entre marinheiros de embarcações menores (até 20 passageiros) e maiores (aproximadamente 100 passageiros), mas a participação geral foi intensa. Dentre os pontos negativos apontados, destacam-se: ausência de caixas sanitárias para banheiros das embarcações; distância das paradas das praias; poluição sonora; falta de suporte do setor público (Prefeitura) no cais; aumento do número de cais particulares; proibição (clandestina) de acesso a algumas praias por seguranças particulares; risco de acidentes nas manobras no cais (excesso de barcos e intolerância das escunas). A seguir, houve um debate sobre formas de mitigar alguns desses problemas. As respectivas sugestões apontadas foram: reservatório para o banheiro dos barcos e local adequado para destinar o esgoto; divisão com bóias, estabelecendo uma área para banhistas e outra para embarcações; permitir o som apenas com o barco em movimento; maior fiscalização. Em seguida, os participantes foram incentivados a produzir seu briefing de apresentação ambiental aos turistas. Com o prosseguimento do Projeto Leme Consciente, espera -se colaborar para o ordenamento náutico em Paraty, gerando, a médio e longo prazo, um "selo verde" para certificar as embarcações que realizam os passeios de forma sustentável.

Palavras-chave: Turismo Náutico; Paraty (RJ); Ecoturismo. 